\title{
Contributions of the Nursing Intervention in Primary Healthcare for the Promotion of Breastfeeding
}

\author{
Luís Carlos Carvalho da Graça ${ }^{1}$ \\ Maria do Céu Barbiéri Figueiredo ${ }^{2}$ \\ Maria Teresa Caetano Carreira Conceição ${ }^{3}$
}

\begin{abstract}
This study aimed to analyze the contributions of the Primary Healthcare nursing interventions, with primiparae in the promotion of breastfeeding. This is a quasi-experimental, longitudinal study, with a sample consisting of 151 primiparae, who had less than 28 weeks of pregnancy, with the child living for at least six months after the birth, performed between 15 October 2007 and 29 February 2008. Almost all the women initiated breastfeeding, with a sharp decline verified in the prevalence at six months. The mean duration of breastfeeding was $123.8 \pm 68.9$ days. The intervention that began in the prepartum and continued into the postpartum period, using various strategies (individual consultation, preparation courses for parenting/childbirth, and domicile visits) and intervention contexts (health services and domicile) had significant effects on the duration of breastfeeding, which was not verified in the prevalence.
\end{abstract}

Descriptors: Nursing Care; Breast Feeding; Nursing.

\footnotetext{
${ }^{1}$ RN, Doctoral student in Nursing, Universidade de Lisboa. Adjunct Professor, Escola Superior de Saúde, Instituo Politécnico de Viana do Castelo, Portugal. E-mail: Icarlosgraca@hotmail.com ; luisgraca@ess.ipvc.pt.

2 RN, Ph.D. in Nursing, Coordinator Professor, Escola Superior de Enfermagem do Porto, Portugal. Ph.D. in Nursing. E-mail: ceubarbieri@esenf.pt.

${ }^{3}$ Chemistry, Ph.D. in Biochemistry, Assistant Professor Retired, Faculdade de Ciências, Universidade de Lisboa, Portugal. E-mail: mteresaccc@gmail.com.
}

Corresponding Author:

Luís Carlos Carvalho da Graça

Instituto Politécnico de Viana do Castelo. Escola Superior de Saúde

Rua D. Moisés Alves de Pinhos

4900-314 Viana do Castelo, Portugal

E-mail: luisgraca@ess.ipvc.pt 


\title{
Contributos da intervenção de enfermagem de cuidados de saúde primários para a promoção do aleitamento materno
}

O presente estudo teve como objetivo analisar os contributos das intervenções de enfermeiras de Cuidados de Saúde Primários, com primíparas, na promoção do aleitamento materno. Trata-se de um desenho quase-experimental, longitudinal, com amostra de 151 primíparas, com menos de 28 semanas de gravidez, entre 15 de outubro de 2007 e 29 de fevereiro de 2008, com filhos vivos aos seis meses após o parto. A quase totalidade das mulheres iniciou o aleitamento materno, verificando-se quebra acentuada da prevalência até os seis meses. A duração média do aleitamento materno foi $123,8 \pm 68,9$ dias. A intervenção que se iniciou no pré-parto e se prolongou para o pós-parto, com diversidade de estratégias (consulta individual; curso de preparação para a parentalidade/parto e visita domiciliária) e contextos de intervenção (serviços de saúde e domicílio), teve efeitos significativos na duração do aleitamento materno, não se verificando na prevalência.

Descritores: Cuidados de Enfermagem; Aleitamento Materno; Enfermagem.

\section{Contribuciones de la intervención de enfermería de cuidados de salud primarios para la promoción del amamantamiento materno}

\begin{abstract}
El presente estudio tuvo como objetivo analizar las contribuciones de las intervenciones de enfermeras de Cuidados de Salud Primarios, con primíparas, en la promoción del amamantamiento materno. Se trata de un estudio casi experimental, longitudinal, con una muestra de 151 primíparas, con menos de 28 semanas de embarazo entre 15 de Octubre de 2.007 y 29 de Febrero de 2.008, con hijos vivos después de seis meses del parto. La casi totalidad de las mujeres inició el amamantamiento materno, verificándose una quiebra acentuada de la prevalencia a los seis meses. La duración promedio del amamantamiento materno fue $123,8 \pm 68,9$ días. La intervención se inició en el preparto y se prolongó para el posparto, con diversidad de estrategias (consulta individual, curso de preparación para la paternidad/parto, y visita domiciliaria) y contextos de intervención (servicios de salud y domicilio) tuvo efectos significativos en la duración del amamantamiento materno, lo que no fue verificando en la prevalencia.
\end{abstract}

Descriptores: Atención de Enfermería; Lactancia Materna; Enfermería.

\section{Introduction}

Breastfeeding is the only natural feeding method for unweaned infants. Based on scientific knowledge, the World Health Organization recommends exclusive breastfeeding during the first six months. After this period, to satisfy the nutritional requirements of the infant, complementary feeding until two years or more is recommended(1). Given these recommendations, it was determine that: i) Exclusive breastfeeding is the administration of breast milk, which includes milk that has been extracted or is from milk banks. Oral rehydration salts, drops and syrups may be administered, however, no other food is permitted; ii) predominant breastfeeding is the administration of breast milk as the main source of food, and other liquids in addition to oral rehydration salts, drops and syrup; iii) complementary breastfeeding is the administration of breast milk and any other food or liquid, which includes milk of animal or artificial origin (2).

The duration and prevalence of breastfeeding presents variations between countries and within countries, although an increase has been verified in recent decades. In the South American countries, between the mid 1980s and mid 1990s, there was an increase in duration, which ranged from +0.5 months in the Dominican Republic to +4.1 months in Peru, with this trend most evident in the urban areas $^{(3)}$. In developing 
countries between 1990 and 2000, the rates of exclusive breastfeeding in children younger than 4 months increased by approximately $15 \%$, being also more evident in the urban zones ${ }^{(4)}$. In the majority of developed countries the rates of initiation of breastfeeding are greater than $90 \%$, decreasing significantly up to six months, observing at this moment exclusive breastfeeding in less than $25 \%$ of children(5). In Portugal there are also high rates of initiation, (above 90\%), with sharp falls over time. At six months the prevalence of breastfeeding is about $30 \%$ and of exclusive breastfeeding around $20 \%{ }^{(6-7)}$. The National Health Plan 2004-2010(8), presented a target for 2010, that the rate of exclusive breastfeeding at 3 months should exceed $50 \%$, which is not linked with international recommendations.

Nurses assume a normalizing and regulating role in the practices of breastfeeding, being considered authorities in establishing the pattern of feeding. The focus of the interventions are the nutritional, immunological, physiological and emotional benefits for the child, based on scientific evidence, not always taking into consideration the psychosocial dimensions ${ }^{(9)}$. The majority of these professionals have updated knowledge about breastfeeding, being more evident in relation to the benefits and duration, and more efficient in theory than in practice ${ }^{(10-11)}$.

There are three preferential opportunities for the promotion of breastfeeding(12). The motivation to breastfeed, the knowledge, beliefs and myths are assessed in the third trimester of pregnancy in which the diet of the child is discussed, where pertinent, relevant and scientifically sustained information should be provided by the professionals in an accessible language, respecting and supporting the choices of the women. Also the quality and extent of the social support network should be evaluated ${ }^{(13)}$. The second opportunity is related to the establishment of lactation. This is a period that normally occurs during the hospitalization in the maternity unit and the nurses need to review what was discussed in the prenatal period, to assist with difficulties in the comprehension of the behavior of the newborn, to evaluate the efficacy of the breastfeeding, to offer instrumental support, to stimulate the help of the social support network ${ }^{(12-13)}$ and to provide conditions for the early initiation of breastfeeding(14). The third opportunity relates to the maintenance of breastfeeding and occurs after discharge. This is a critical period, in which the woman leaves a safe environment, with a network of professional proximity, to return to an environment in which she will have to resolve the needs independently ${ }^{(12)}$. During this period the domicile visit is important to ensure a safe transition between the hospital and the domicile(13).

The effects of the interventions on the prevalence and duration of breastfeeding are heterogeneous, proving to be most effective when they involve interaction(15-16). The measures of the Baby Friendly Hospital Initiative, are those which have been found to be most effective ${ }^{(16-21)}$, and the domicile visits presents heterogeneous results(15-16,22), observing the doseresponse association. Support groups that include professionals and peer groups, intervention programs that articulate the health education, the support, the help and the information campaigns in the media, in combination with structural alterations in the health sector, have proven to be effective ${ }^{(15-16,23)}$. Interventions that begin shortly before delivery, continue for the postpartum, and extend through time, are more effective than those that limit themselves to one of the periods.

In Portugal, particularly in the northern region, there were alterations in the organization and functioning of the Primary Healthcare System, with the provision of preparation for childbirth/parenthood courses and the progressive generalization of domicile visits to the newborn, which aimed to contribute to achieving the goals of the National Health Plan 2004-2010(8), with reference to the prevalence of breastfeeding.

Thus, the present study aimed to analyze the contributions of the interventions of Primary Healthcare nurses, with primiparae in the promotion of breastfeeding.

\section{Method}

Given the aim of the study, a quasi-experimental study was designed using interventions that were performed by the nurses of Health Centers in the district of Viana do Castelo, northern Portugal. In the study design there exists three moments of data collection (O1; 02; and 03). In the first $\left(26^{\text {th }}\right.$ to $28^{\text {th }}$ week of pregnancy), the background and expectations of breastfeeding were evaluated, as well as the similarities between the groups, in the second and third (first and sixth month postpartum) the prevalence and duration of breastfeeding was evaluated.

The independent variable is the mode of nursing intervention, which stems from the clinical practice of the nurses in the Health Centers of the district. All primiparae had individual consultations in which health education related to breastfeeding was performed. The primiparae in groups A and B participated in courses 
to prepare for childbirth/parenthood (Xgr) that began from the $28^{\text {th }}$ week of pregnancy. These courses were conducted by specialist nurses in Maternal Health and Obstetrics Nursing, in group sessions, which had, among other objectives: i) to promote breastfeeding and ii) to facilitate the exchange of experiences among the pregnant women ${ }^{(24)}$. Theoretical and practical components were integrated, with the women taking the initiative to participate. The criterion for inclusion in these groups was to participate in at least six sessions of the course. The primiparae of group $B$ received a domicile visit (Xvd) after the $15^{\text {th }}$ day postpartum, which aimed to provide additional information to that provided in the Health Center and to respond to their needs in their life contexts. It had a duration that did not usually exceed 60 minutes. The dependent variable is the prevalence and duration of breastfeeding. With this design, the existence of groups in which in three administrations of the same instruments are performed (01, $\mathrm{O} 2$ and 03), permits the differences between the various moments to be analyzed and the effects of the modes of intervention and maturation to be differentiated.

With the primiparae of group $D$, data collection was only performed at six months, to allow the control of possible effects due to learning the instrument (Table 1 ). As the effect of the pre-test was controlled, the effect of the pre-partum intervention (Xgr) was compared with the effect of the intervention in the pre- and postpartum (Xgr and Xvd) and with the effect of the natural intervention (individual consultation only), allowing the effects of the modes of intervention to be evidenced.The study was longitudinal and blind since the primiparae were unaware of the study design or to which group they belonged.

Table 1 - Study design, with distribution of the groups according to the intervention of the nurses

\begin{tabular}{|c|c|c|c|c|c|}
\hline Cohort & $\begin{array}{c}26^{\text {th }}-28^{\text {th }} \text { week } \\
\text { pregnant }\end{array}$ & $\begin{array}{c}\text { From the } 26^{\text {th }}-28^{\text {th }} \text { week } \\
\text { pregnant to delivery }\end{array}$ & $\begin{array}{c}\text { Until } 15 \text { days after } \\
\text { delivery }\end{array}$ & $\begin{array}{c}1^{\text {st }} \text { month } \\
\text { postpartum }\end{array}$ & $\begin{array}{c}6^{\text {th }} \text { month } \\
\text { postpartum }\end{array}$ \\
\hline A & $\mathrm{O} 1^{*}$ & $\mathrm{X} \mathrm{gr}{ }^{\dagger}$ & & $\mathrm{O} 2^{\ddagger}$ & O3§ \\
\hline B & 01 & $\mathrm{Xgr}$ & $X v d \|$ & $\mathrm{O} 2$ & $\mathrm{O} 3$ \\
\hline $\mathrm{C}$ & O1 & & & $\mathrm{O} 2$ & O3 \\
\hline $\mathrm{D}$ & & & & & $\mathrm{O} 3$ \\
\hline
\end{tabular}

${ }^{*}$ Initial evaluation

${ }^{+}$Health education in groups (preparation courses for parenthood/childbirth)

־Second data collection moment

sThird data collection moment

"Domicile visit

According to the reasoning and considering the research problems, the following hypotheses were formulated:

$\mathrm{H} 1$ - The prevalence of breastfeeding is influenced by the interventions of the nurses. More primiparae with intervention in pre-and postpartum administer breast milk, than of the other cohorts.

$\mathrm{H} 2$ - The duration of breastfeeding is influenced by the interventions of the nurses. The primiparae that received intervention in the pre-and postpartum breastfeed for longer than the others.

For this study an objective sample was selected, which included all primiparae who were enrolled in the Health Centers of the district of Viana do Castelo with less than 28 weeks of pregnancy between 15 October 2007 and 29 February 2008 and were available to take part, data collection was ongoing from 15 October 2007 and 15 December 2008. The distribution into the groups was carried out at the second stage of data collection, after knowing the mode of intervention that the primiparae had been exposed to. At the end of the data collection period, the sample consisted of 151 primiparae, integrating $19.2 \%$ group $A ; 16.6 \%$ group $\mathrm{B} ; 47.7 \%$ group $\mathrm{C}$; and $16.6 \%$ of group D. Between the start and finish of the study $11 \%$ of the women were being "lost" due to change of residence, being uncontactable, no longer wanting to continue in the study, and due to questionnaires filled out incorrectly. The data collection instrument was a self-completion questionnaire constructed for this purpose.

The study was authorized by the Regional Health Administration and the participants were informed of the objectives, assured of confidentiality and anonymity, and signed the Terms of Free Prior Informed Consent. For data analysis descriptive and inferential statistical techniques were used, making use of parametric tests whenever they met the premise provided for their use. For the hypothesis testing ANOVA was used with one nominal factor, and to test independence the chi-square test was used. The significance level chosen was $5 \%$. For information processing, the software SPSS 17.0 for Windows was used.

\section{Results}

The primiparae were between 18 and 38 years of age, with a mean of $28.4 \pm 4.27$ years. The majority of the women were married or living with a partner 
$(90.7 \%)$, in nuclear families (75.5\%) and, regarding schooling, $44.4 \%$ had basic education and $21.2 \%$ tertiary education. There was a predominance of manual workers, artisans and similar workers (27.8\%), services personal and saleswomen (15.2\%) and specialists in intellectual and scientific professions (14.6\%). The level of schooling presented statistically significant differences $\left(X^{2}{ }_{\mathrm{KW}(3)}=15.973 ; p=0.001\right)$, verifying that the primiparous of the cohort with intervention in the preand postpartum present superior levels of education to those of the natural and control cohorts, they also presented more diverse professions $\left(X_{(6)}^{2}=16.533\right.$; $p=0.011)$. Among the other variables no differences were verified. For $64.2 \%$ of the women the pregnancy care was exclusively through individual consultations and $35.8 \%$ cumulatively attended preparation for childbirth/parenthood classes. Single child pregnancies
(98.7\%) and vaginal delivery (67.5\%) predominated. The majority of the women were breastfed as infants $(81.3 \%)$, relate to women that breastfeed $(66.5 \%)$ and intend to breastfeed (96.3\%).

Breastfeeding was initiated by almost all of the women $(97.4 \%)$, with $49.0 \%$ of the newborns being breastfed within the first hour of life. In the first month after the birth, the prevalence rate of breastfeeding was $79.9 \%$, falling to $37.1 \%$ by the sixth month. With regard to exclusive breastfeeding, the prevalence was $41.0 \%$ falling to $2 \%$ by the sixth month, and for predominant breastfeeding it was $18.7 \%$ falling to $17.9 \%$. Among the cohorts there were no statistically significant differences (Table 2), regarding the $\mathrm{H} 1$ hypothesis, that the prevalence of breastfeeding is influenced by the interventions of nurses not being confirmed.

Table 2 - Distribution of the differences between the groups regarding the prevalence of breastfeeding in primiparae of Viana do Castelo, in $2008(n=151)$

\begin{tabular}{|c|c|c|c|c|c|c|}
\hline \multirow[b]{2}{*}{ Variable } & \multicolumn{3}{|c|}{$1^{\text {st }}$ month postpartum } & \multicolumn{3}{|c|}{$6^{\text {th }}$ month postpartum } \\
\hline & V. test & gl & sig & V. test & gl & sig \\
\hline Breastfeeding $^{\star}$ & 4.443 & 2 & 0.108 & 6.909 & 3 & 0.075 \\
\hline Exclusive breastfeeding ${ }^{*}$ & 2.195 & 2 & 0.334 & & & \\
\hline Predominant breastfeeding ${ }^{*}$ & 2.533 & 2 & 0.282 & 1.896 & 3 & 0.594 \\
\hline
\end{tabular}

${ }^{*}$ Chi Square Test of Independence

Concerning the duration of breastfeeding, there were significant differences between the cohorts (One Way ANOVA: $\left.F_{(3,147)}=2.692 ; p=0.048\right)$, with the multiple comparisons of means (Tukey's test) presenting differences between the primiparae of the natural cohort

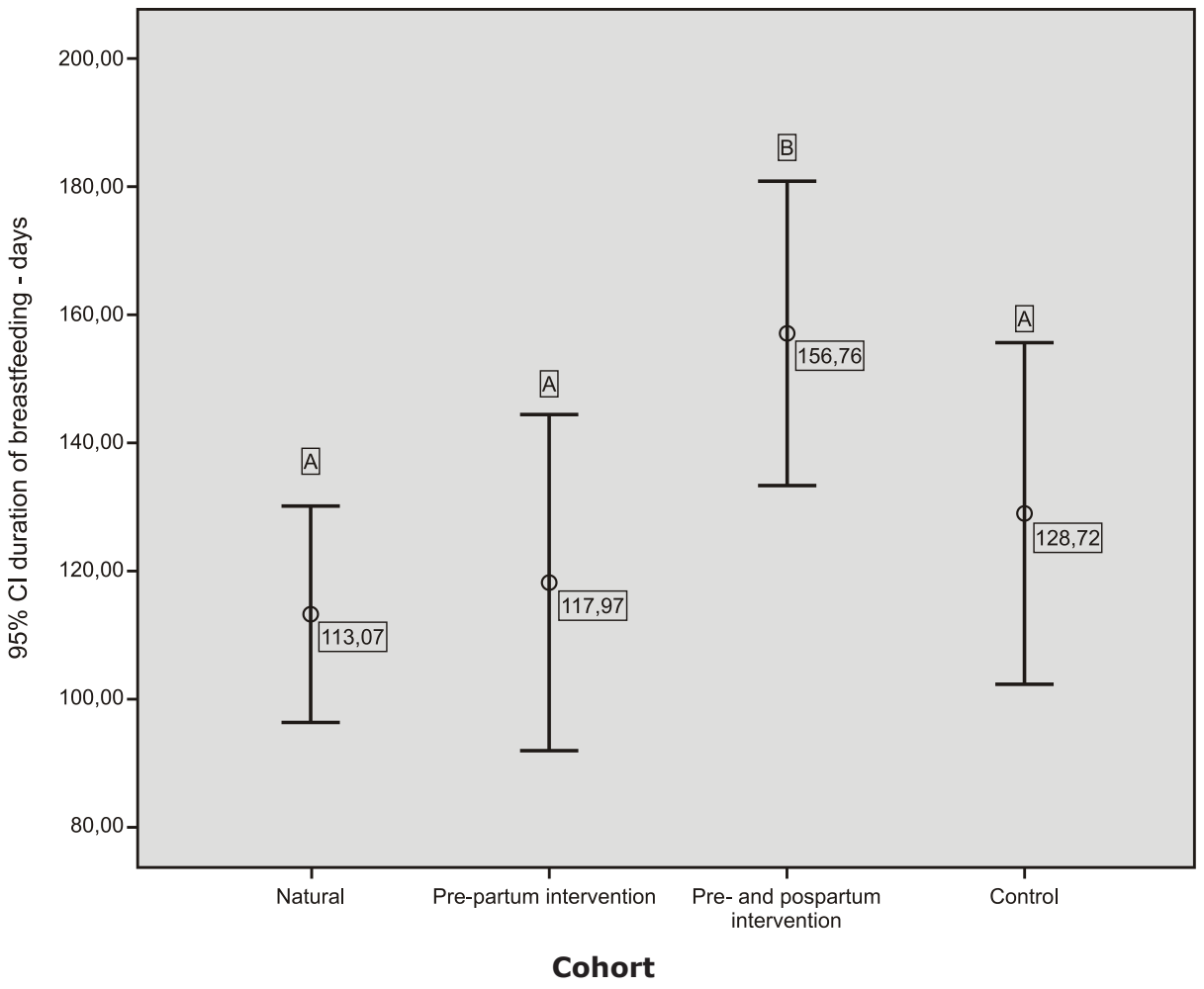

The means marked with different letters are statistically different

Figure 1 - Distribution of the mean duration of breastfeeding in primiparae of the district of Viana do Castelo, according to group, in $2008(n=151)$ 
and those of the pre- and postpartum intervention cohort $(p=0.031)$. The women of group $C$, who had only individual consultation, on average, breastfeed for

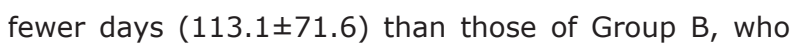
participated in individual consultations, preparation for childbirth/parenthood courses and received domicile visits $(156.7 \pm 57.4)$. The primiparae of group $B$, who received individual consultations and participated in childbirth preparation courses $(118.0 \pm 68.9)$ and those of group D (128.8 \pm 64.2$)$ presented mean values close to that of group $\mathrm{C}$ for duration. The overall mean was 123.8 \pm 68.9 days (Figure 1 ), confirming the $\mathrm{H} 2$ hypothesis that the duration of breastfeeding is influenced by the interventions of nurses. The primiparae that received intervention in the pre- and postpartum breastfeed for longer than the others.

\section{Discussion}

Breastfeeding has been the subject of various studies in diverse areas of knowledge, aiming to respond to the diversity of problems. These studies have investigated the incidence, prevalence and duration; determinant factors of adherence; effects on the health of the woman, children and adults; efficacy of the interventions of the professionals, peer groups, policies, etc, allowing the investigation to produce guidelines on the best practices $^{(1)}$. The realities of the different countries and between the countries are heterogeneous, often poorly known, the indicators are not comparable, there is lack of implementation of international recommendations, the professionals have inadequate training and the projects are unlinked and rarely evaluated.

With this study the evaluation was intended of the effects of the interventions of nurses of the Health Centers on the prevalence and duration of breastfeeding. In the prepartum period the majority of the women reported having been breastfed $(81.3 \%)$, and in the social network to which they relate, the majority of women (66.5\%) breastfeed and almost all (96.3\%) intended to breastfeed, being facilitator factors of successful breastfeeding. The socio-demographic characteristics, of healthcare and of predisposition to breastfeeding, were identical among the women of the different cohorts, with the exception of schooling, which was higher among those who received intervention in pre- and postpartum, however an analysis of covariance did not verify that this would influence the dependent variables.

Almost all the women, according to their expectations, initiated breastfeeding (97.4\%), with the rate being identical to that observed in other studies in Portugal(6-7), similar to that of Nordic countries such as Sweden or Norway ( $>95 \%$ ) and higher than the majority of industrialized countries ${ }^{(5)}$. The prevalence of breastfeeding decreased substantially over time. In the first month $79.9 \%$ of the women continued breastfeeding and in the sixth month $37.1 \%$, with these rates identical to those of other studies in Portugal(6-7), denoting little geographical variation. This was not influenced by the nursing intervention, however, in the sixth month, when considering a significance level of $10 \%$, there were more primiparae who received intervention in preand postnatal periods that administered breast milk, suggesting that continued intervention from prepartum to postpartum and in different contexts can have an effect on breastfeeding. Exclusive breastfeeding also decreases over time. In the first month after the birth this represented $41 \%$, with $2 \%$ at six months, attesting to the inferiority of the first month in relation to the target of the National Health Plan.

The prevalence of predominant breastfeeding in the first months was $20.2 \%$ and $19.9 \%$ of the sixth. This type of feeding arises from the introduction of water or tea, which is influenced by the practices of generations and by the social support network, which is considered a predictor for the cessation of exclusive breastfeeding and of breastfeeding(25). The mean of days of breastfeeding was $123.8 \pm 68.9$, being below the mean duration of the women who received intervention in the pre- and postpartum (156.7 \pm 57.4$)$ verifying that the Nursing intervention, in different contexts and spread over time, contributes to a longer duration. Health professionals are considered experts in the area of nutrition for infants, assuming a role as regulator and normalizer(9) and are in a unique position to provide instrumental, informational and social support.

The continuity of intervention, from the prepartum to the postpartum, occurred with all the women with the individual consultation. When the participation occurred in preparation courses for parenting/ childbirth and domicile visits, marginal effects on the prevalence of breastfeeding and more evident effects on the duration were verified. As in other studies, the diversity of strategies, contexts of intervention and their continuity were shown to contribute to the success of breastfeeding ${ }^{(15-16,23)}$.

\section{Conclusions}

Breastfeeding was initiated with almost all the 
newborns and with nearly half of them during the first hour of life, which is a predictor for its success. The prevalence of breastfeeding suffered sharp falls over time ( 1 month - 79.9\%; 6 months - 37.1\%) with exclusive breastfeeding presenting identical behavior ( $41 \%$ falling to $2 \%$ ). The nursing intervention was not a determinant for the prevalence of breastfeeding, however, at six months the proportion of primiparae in group B (intervention in the pre- and postpartum) breastfeeding was greater than that of the other groups. The observation of no differences may be related to cultural aspects and the return to work, however, this may also be due to the small sample size. The duration of breastfeeding was higher in group $B$ (intervention in pre- and postpartum), showing that the intervention initiated during pregnancy and continued after the birth, with a diversity of strategies and intervention contexts is more effective.

For the promotion of breastfeeding to be more effective, as well as the promotion of health, it should be based on five pillars: i) to establish policies favorable to breastfeeding, based on the implementation of international recommendations, inter-ministerial articulation, social support, and clear definition and disclosure of the policies; ii) to create supportive environments for breastfeeding, stimulating spaces that facilitate privacy for breastfeeding and motherchild contact; iii) to reinforce community action through the promotion of peer networks, which enable mutual support and apply pressure on policy makers for the implementation of policies that facilitate breastfeeding; iv) to develop personal skills, through information, education and skills training, based on the best practices of Health Education; v) to reorganize health services, with the implementation of evidence-based practices, which include the guidelines of the International Code of Marketing of Breast-Milk Substitutes, the measures of the Baby Friendly Hospital Initiative, improved academic and continuous training of the professionals, the implementation of institutional project, monitoring and evaluation of the practices of health services, among others.

The contribution of this study for nursing education and practice is supported in the meaning of what the discipline is, in the theoretical models that provide guidance and in the social responsibility with the intervention, with the role of the educational institutions to educate for excellence in care. The nurses, in the sphere of their autonomous interventions, are expected to plan, execute and evaluate the care in order to contribute to more and better health.

The study results may have been influenced by variables that were not controlled, including beliefs and values relating to breastfeeding. Cumulatively, in addition to the nursing intervention, the women may have had access to other sources of information and social support networks, which is presumed to have influenced women of different groups in an identical way. While this quasi-experimental study took advantage of the interventions of the health professionals, neither the content nor the intervention strategies were controlled. It would be desirable to control the interventions because there could be implications in the professional practices, conditioning them, and, consequently, in the evaluation of their efficacy.

An experimental study would be more robust, permitting the control of the intervention, such as the randomization of the participants by their cohorts. However, this would not permit the evaluation of the efficacy of the interventions which are currently implemented in the Health Centers.

\section{References}

1. World Health Assembly (WHA) 54.7. Global strategy for infant and young child feeding: report by the Secretariat. 2001. [acesso 14 set 2008]. Disponível em: http://apps. who.int/gb/archive/pdf_files/WHA54/ea547.pdf.

2. World Health Organization (WHO). Indicadores para evaluar las prácticas de alimentación del lactante y del niño pequeño: parte I - definiciones. 2009. [acesso 20 dez 2009]. Disponível em: http://whqlibdoc.who.int/ publications/2009/9789243596662_spa.pdf.

3. Pérez-Escamilla R. Breastfeeding and the nutritional transition in the Latin American and Carabbean Region: a success story? Cad Saúde Pública. 2003;19(Suppl 1):S119-27.

4. Labbok MH, Wardlaw T, Blanc A, Clark D, Terreri N. Trends in exclusive breastfeeding: findings from the 1990s. J Human Lactation. 2006;22(3):272-6.

5. World Health Orzanization (WHO). Infant and young child feeding data by country. 2009. [acesso 29 dez. 2009]. Disponível em: http://www.who.int/nutrition/ databases/infantfeeding/countries/en/index.html>.

6. Safarana S, Abecasis F, Tavares A, Soares I, Gomes A. Aleitamento materno: evolução na última década. Acta Pediátr Portuguesa. 2006;1(37):9-14.

7. Sandes AR, Nascimento C, Figueira J, Gouveia R, Valente S, Martins $S$, et al. Aleitamento Materno: prevalência e factores condicionantes. Acta Méd 
Portuguesa. 2007;20:193-200.

8. Ministério da Saúde (PT). Direcção-Geral da Saúde. Plano Nacional de Saúde 2004-2010. Lisboa: DirecçãoGeral da Saúde; 2004. 216 p.

9. Nakano AM. O espaço social das mulheres e a referência para o cuidado na prática da amamentação. Rev. Latino-Am. Enfermagem. 2007;15(2):230-8.

10. Caldeira AP, Nobre de Aguiar G, Magalhães WAC, Fagundes GC. Conhecimentos e práticas de promoção do aleitamento materno em equipes de Saúde da Família em Montes Claros, Minas Gerais, Brasil. Cad Saúde Pública. 2007;23(8):1965-70.

11. Bassichetto KC, Réa MF. Aconselhamento em alimentação infantil: um estudo de intervenção. J Pediatria. 2008;84(1):75-82.

12. Levy L, Bértolo H. Manual de Aleitamento Materno. Lisboa: Comité Português para a UNICEF; 2008. 44 p.

13. Tamez RN. Atuação de Enfermagem. In Renato de Carvalho M, Tamez RN. Amamentação: bases científicas para a prática profissional. Rio de Janeiro: Guanabara Koogan; 2002. p. 115-31.

14. Bueno LG, Teruya KM. Aconselhamento em amamentação e sua prática. J Pediatria. 2004;80(5):S126-30.

15. Couto de Oliveira MI, Camacho LA, Tedstone AE. Extending Breastfeeding Duration Through Primary Care: A Systematic Review of Prenatal and Postnatal Interventions. J Human Lactation. 2001;17(4):326-43.

16. Hannula L, Kaunonen M, Tarkka MT. A systematic review of professional support interventions for breastfeeding. J Clin Nurs. 2008;19(7):1132-43.

17. Kramer MS, Chalmers B, Hodnett ED, Sevkovskaya Z, Dzikovich I, Collet JP, et al. Promotion of breastfeeding intervention trial (PROBIT): a randomized trial in the Republic of Belarus. JAMA. 2001;285(4):413-20.

18. Merten S, Dratva J, Ackermann-Liebrich U. Do BabyFriendly Hospitals influence breastfeeding duration on a national level? Pediatrics. 2005;116(5):e702-8.

19. Vitolo MR, Bortoloni GA, Feldens, CA, Drachler ML. Impacto da implantação dos dez passos da alimentação saudável para crianças: ensaio de campo randomizado. Cad Saúde Pública. 2005;21(5):1448-57.

20. Caldeira AP, Gonçalves E. Avaliação de impacto da implantação da Iniciativa Hospital Amigo da Criança. J Pediatria. 2007;83(2):127-32.

21. Mydlilova A, Sipek A, Vignerova J. Breastfeeding rates in Baby-Friendly an non-Baby-Friendly Hospitals in Czech Republic from 2000 to 2006. J Human Lactation. 2009;25(1):73-8.

22. Zadoroznyj M. Postnatal care in the community: report of an evaluation of birthing women's assessments of a postnatal home care programme. Health Soc Care Commun. 2006;15(1):35-44.

23. McDonald SJ, Henderson JJ, Faulkner S, Evans SF, Hagan R. Effect of an extended midwifery postnatal support programme on the duration of breast feeding: a randomised controlled trial. Midwifery. 2010;26(1):88-110.

24. Administração Regional de Saúde Norte (ARS Norte). Preparação para o parto e para a parentalidade. 2006. [acesso 01 nov 2009], Disponível em: http://portal.arsnorte.min-saude.pt/ portal/page/portal/ARSNorte/Conte\%C3\%BAdos/ Institui\%C3\%A7\%C3\%B5es/Viana\%20do\%20Castelo/ Prepara\%C3\%A 7\%C3\%A30\%20 para\%200\%20 parto $\% 20$ e $\% 20$ para $\% 20$ a $\% 20$ parentalidade $\% 20$ saud\%C3\%A1veis9.

25. Araújo de França GV, Brunken GS, Silva SM, Escuder MM, Venancio SI. Determinantes da amamentação no primeiro ano de vida em Cuiabá, Mato Grosso. Rev Saúde Pública. 2007;41(5):711-8.
Received: Sep. $2^{\text {nd }} 2009$ Accepted: Feb. 24th 2011 